\title{
CONSTITUTIVE EQUATION OF BUTTER AT STATIC LOADING
}

\author{
Š. Nedomová, L. Severa \\ Received: March 13, 2008
}

\begin{abstract}
NEDOMOVÁ, Š., SEVERA, L.: Constitutive equation of butter at static loading. Acta univ. agric. et silvic. Mendel. Brun., 2008, LVI, No. 5, pp. 147-152

This study focuses on the constitutive modelling of finite deformation in the commercially obtained butter (composition is $83 \%$ of milk fat) at the temperature $17-20{ }^{\circ} \mathrm{C}$. The specimens from the butter (height $L_{0}=14.6 \mathrm{~mm}$ and diameter $20 \mathrm{~mm}$ ) have been compressed between two parallel metal plates at a fixed crosshead speed $20 \mathrm{~mm} / \mathrm{min}$ using of the testing device TIRA TEST. The force $F$ and the deformation $\Delta L$ are measured during compression and both quantities are recorded. The experimental records force F - displacement (deformation) were obtained. These records have been transformed into stress-strain dependences and into true stress-true strain. The basic data on the strain behaviour of a butter under low strain rates have been obtained. Experimental results show that the behaviour of butter can be described by a hyperelastic material model. In this model, the quasi-static response is defined by compressible hyperelasticity, whereby the strain energy potential is assumed to be representable by a newly proposed polynomial series with three independent parameters. The material parameters in the constitutive model are determined from compression test. A comparison of predictions based on the proposed constitutive equation with experiments shows that the model is able to describe the strain behaviour of the butter examined.
\end{abstract}

butter, compression, strain, stress, constitutive equation

The traditional end use of surplus milk fat is butter. Its rheological properties are described in many papers, see Enjalbert et al. (2000) for a review. Most of these papers is focused on some flow properties of the butter which are typical for temperatures above about $25^{\circ} \mathrm{C}$. At cooling temperatures $\left(5\right.$ to $10{ }^{\circ} \mathrm{C}$ ), butter behaves like a solid and has poor spreadability. The information about butter behaviour at temperatures lying between these two regions is very rare if not missing.

The aim of this paper consists in the study of a proper constitutive model for butter at the temperatures between 17 (SPECIMEN 1; 3) - $20^{\circ} \mathrm{C}$ (SPECIMEN 2; 4). To begin with, its mechanical properties under compression, up to engineering strains of about $80 \%$, are characterized experimentally. Owing to some similarities with the experimental results obtained for elastomeric foams (Zhang et al., 1997) a hyperelastic constitutive relationship is formulated to describe the material properties. In this model, the quasi-static response is first defined from the standpoint of compressible hyperelasticity.

\section{MATERIAL AND EXPERIMENTAL TECHNIQUE}

For the experiments the commercially obtained butter has been used. Its composition is $83 \%$ of milk fat. From the butter a cylindrical sample of height $L_{0}=14.6 \mathrm{~mm}$ and diameter $20 \mathrm{~mm}$ have been prepared. These specimens from the same butter have been compressed between two parallel metal plates at a fixed crosshead speed $20 \mathrm{~mm} / \mathrm{min}$ using of the testing device TIRA TEST. The force $F$ and the deformation $\Delta L$ are measured during compression and both quantities are recorded. The force-deformation data may easily be transformed into normalized quantities such as stress and strain. Among these measures, the Cauchy strain and Hencky's natural or 'true' strain are of common use in representing compression curves. The Cauchy strain measure gives the relative deformation with respect to the initial sample height

$$
\varepsilon_{C}=\frac{\Delta \mathrm{L}}{\mathrm{L}_{0}} .
$$


Hencky's strain often denoted as 'true' strain derives from the integration of the infinitesimal strain and is given by

$$
\varepsilon_{H}=-\ln \left(\frac{L_{0}-\Delta L}{L_{0}}\right)=-\ln \left(1-\varepsilon_{C}\right) .
$$

The conversion of the force $F$ into engineering stress is simple given by

$$
\sigma_{u}=\frac{F}{A_{0}},
$$

where $A_{0}$ is the cross section of the undeformed specimen. In order to obtain some information on the true stress an assumption on the material incompressibility is used. The true stress is than given by

$$
\sigma_{t}=\sigma_{u}\left(1-\varepsilon_{C}\right) .
$$

The transformation force-deformation data into quantities given above have been performed using of MATLAB software.

\section{EXPERIMENTAL RESULTS}

In Fig. 1 the examples of the experimental records force F - displacement (deformation) are shown. One can see a scatter of data. These records have been transformed into stress-strain dependences see Fig. 2 and into true stress-true strain - see Fig. 3. The dependence true stress-true strain can be fitted by a polynom:

$$
\sigma_{t}=a \varepsilon_{t}^{3}+b \varepsilon_{t}^{2}+c \varepsilon_{t}
$$

The parameters a, b, c are given in the Table I.

I: Parameters of the curve fitting

\begin{tabular}{|c|c|c|c|c|}
\hline SPECIMEN & $\mathrm{a}(\mathrm{kPa})$ & $\mathrm{b}(\mathrm{kPa})$ & $\mathrm{c}(\mathrm{kPa})$ & $\mathrm{R}^{2}$ \\
\hline 1 & 0.5148 & -0.4034 & 0.1487 & 0.9943 \\
\hline 2 & 0.4346 & -0.3976 & 0.1334 & 0.9985 \\
\hline 3 & 0.5173 & -0.3666 & 0.1016 & 0.9983 \\
\hline 4 & 0.4003 & -0.3404 & 0.1103 & 0.9992 \\
\hline
\end{tabular}

The correlation $\mathrm{R}^{2}$ is very high. The parameter $c$ corresponds to some instantaneous modulus $\mathrm{E}$ :

$$
E=\frac{\partial \sigma_{t}}{\partial \varepsilon_{t}} \mid \varepsilon_{t}=0 \equiv c .
$$

As it has been remarked the obtained data are very similar to those obtained for elastomeric foams (Wang and Yang, 1992). It has been shown that these data can be described in the framework of a hyperelastic constitutive relationship. The basic description of this model is presented in the following section.

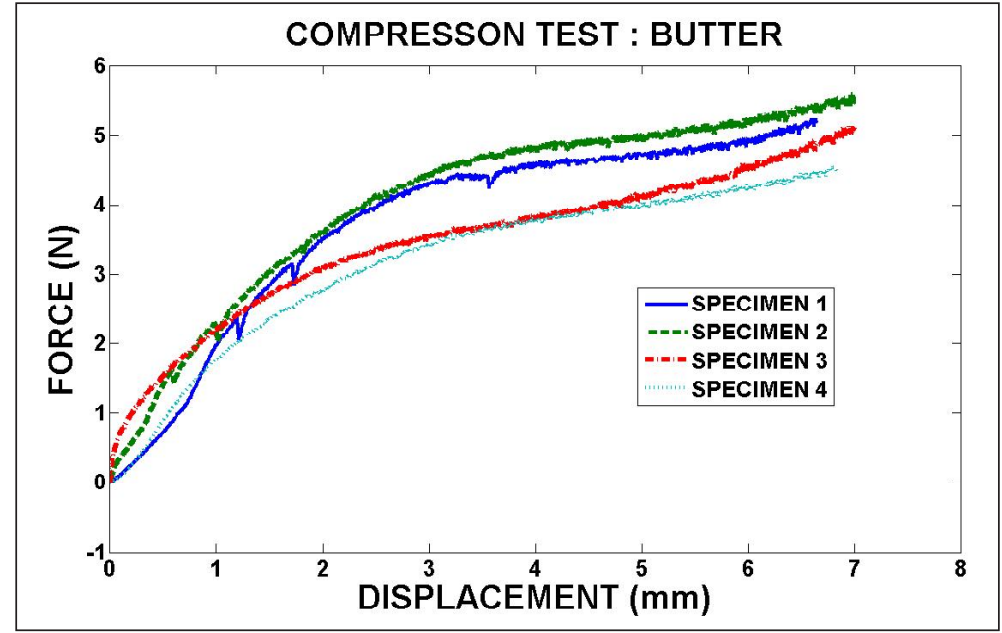

1: Examples of the force-displacement record 


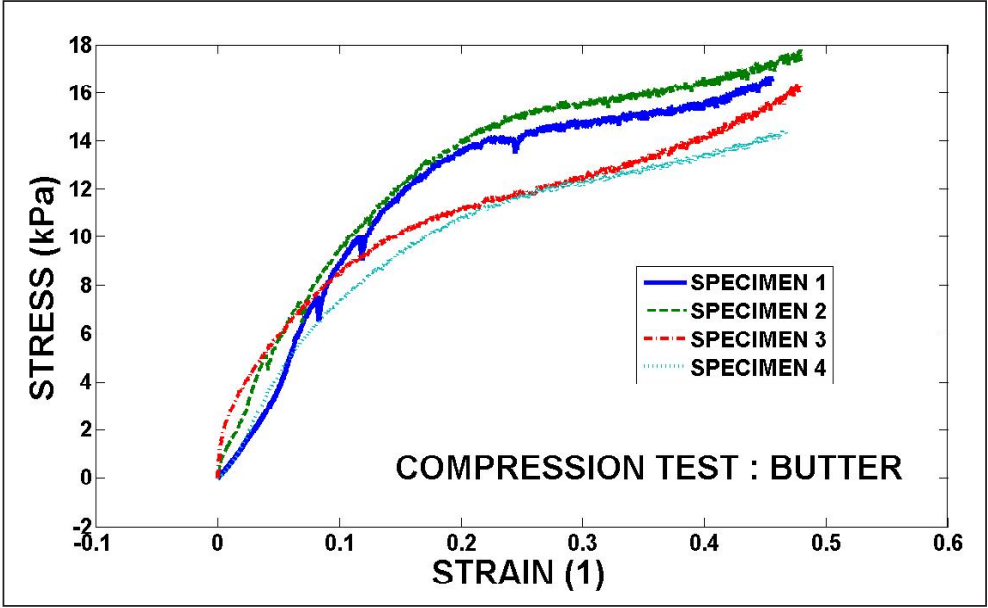

2: Force-displacement data transformed into engineering stress-strain dependences

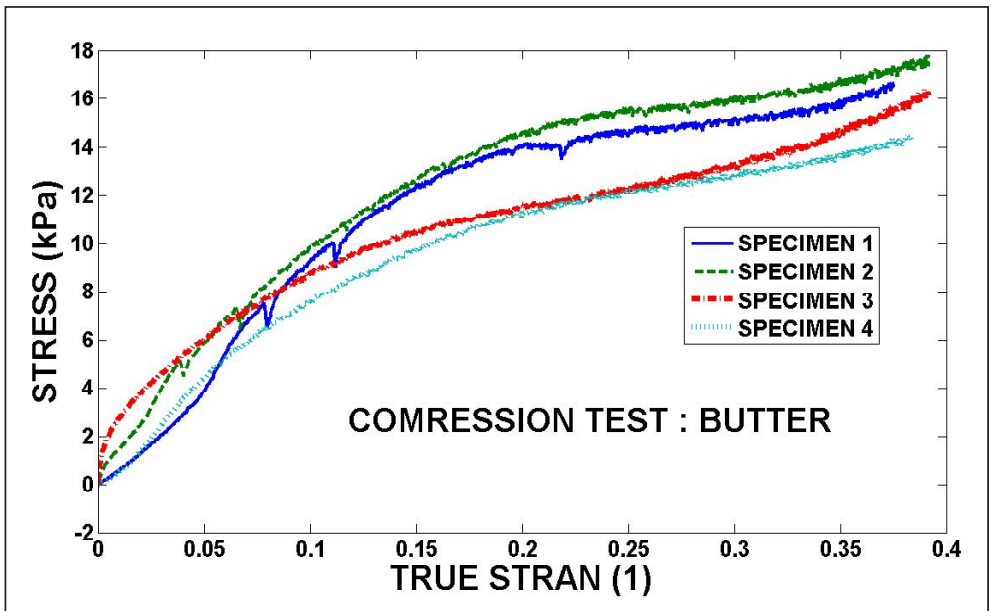

3: Force-displacement data transformed into true stress-true strain dependences

\section{PROPOSAL OF THE CONSTITUTIVE EQUATION}

Consider a point initially located at some position $X$ in a material. Displacement to a new position $x$ after deformation results in a deformation gradient $F$ defined by: $F=\partial x / \partial X$. Deformation of the material can be described by the left Cauchy-Green deformation tensor $\mathrm{B}=\left(\mathrm{F} . \mathrm{F}^{\mathrm{T}}\right)$, or by the right CauchyGreen tensor $C=\left(F^{\mathrm{T}} . \mathrm{F}\right)$, which is related to the Green strain tensor $\mathrm{E}=(\mathrm{C}-\mathrm{I}) / 2$. The three invariants of $\mathrm{B}$ are defined as

$$
I_{1}=\operatorname{tr}(B), I_{2}=\frac{I_{1}^{2}-\operatorname{tr}\left(B^{2}\right)}{2}, I_{3}=\operatorname{det}(B) .
$$

Following the analysis of Rivlin (1960), the constitutive relationship for an isotropic compressible hyperelastic material can be expressed by Lockett (1972):

$\sigma^{e}=\alpha_{0} I+\alpha_{1} B+\alpha_{2} B \cdot B$,

where $\alpha_{0}=2 I_{3}^{-\frac{1}{2}} \frac{\partial W}{\partial I_{3}}, \alpha_{1}=2 I_{3}^{-\frac{1}{2}}\left(\frac{\partial W}{\partial I_{1}}+I_{1} \frac{\partial W}{\partial I_{2}}\right)$,

$\alpha_{2}=-2 I_{3}^{-\frac{1}{2}} \frac{\partial W}{\partial I_{2}}$

and $\sigma^{\mathrm{e}}$ is the Cauchy stress tensor, $W=\left(I_{1}, I_{2}, I_{3}\right)$ is a strain energy potential which is assumed to be representable by a polynomial series involving $\left(I_{1}-3\right),\left(I_{2}\right.$ - 3), and $I_{3}$, where $I_{3}$ represents the effects of volume deformation on the behaviour. It holds

$W=C_{00}+C_{10}\left(I_{1}-3\right)+C_{01}\left(I_{2}-3\right)+C_{20}\left(I_{1}-3\right)^{2}++C_{11}\left(I_{1}-3\right)$ $\left(I_{2}-3\right)+C_{02}\left(I_{2}-3\right)^{2}+\ldots$,

where $C_{i j}$ are material parameters. For compressible materials $W$ increases while $I_{3}$ decreases. Hence the following series is used for an approximation for $W$ :

$W=I_{3}{ }^{-\beta}\left[A_{10}+A_{11}\left(I_{1}-3\right)+A_{12}\left(I_{2}-3\right)+A_{13}\left(I_{1}-3\right)^{2}+\right.$ $\left.A_{14}\left(I_{1}-3\right)\left(I_{2}-3\right)+\ldots\right]+I_{3}^{-\beta-1}\left[A_{20}+A_{21}\left(I_{1}-3\right)+A_{22}\left(I_{2}-\right.\right.$ $\left.3)+A_{23}\left(I_{1}-3\right)^{2}+\ldots\right]+I_{3}^{-\beta-2}\left[A_{30}+A_{31}\left(I_{1}-3\right)+A_{32}\left(I_{2}-3\right)\right.$ $\left.+A_{33}\left(I_{1}-3\right)^{2}+\ldots\right]+\ldots(\beta \geq 0)$. 
From the stress-strain curves of the two foams studied, the following simplified strain energy potential function is found to be suitable for describing the material response, i.e.

$W=I_{3}^{-\frac{1}{2}}\left[A_{0}+A_{1}\left(I_{1}-3\right)+A_{2}\left(I_{2}-3\right)+A_{3}\left(I_{1}-3\right)^{2}+A_{4}\left(I_{2}-3\right)^{2}\right]$ $+I_{3}^{-\frac{3}{2}}\left[A_{5}+A_{6}\left(I_{1}-3\right)+A_{7}\left(I_{2}-3\right)\right]$,

where $A_{i}(\mathrm{i}=0 . . .7)$ are material constants determined from tests involving one-dimensional loading. In Eq. (3), the term $\left(I_{1}-3\right),\left(I_{2}-3\right)$ is omitted to reduce the number of parameters in the proposed model (a comparison between the fitted curves and experimental data shows that omission of this term does not affect the quality of the fit). The description of the strain energy potential function in this form, for compressible foams, has not been previously proposed. Consider the uniaxial loading of a specimen; it is assumed that there is no deformation in the direction perpendicular to that of the load application. Let the stretch in the loading direction be denoted by $\lambda$; consequently, the principle stretches are $\lambda_{1}=\lambda$, $\lambda_{2}=\lambda_{3}=1$. The resulting deformation gradient $F$ and left Cauchy-Green deformation tensor B (for uniaxial loading, $\mathrm{B}=\mathrm{C}$ ) are

$$
F=\left[\begin{array}{lll}
\lambda & 0 & 0 \\
0 & 1 & \\
0 & 0 & 1
\end{array}\right] \quad B=F \cdot F^{T}\left[\begin{array}{lll}
\lambda^{2} & 0 & 0 \\
0 & 1 & \\
0 & 0 & 1
\end{array}\right] .
$$

The invariants are therefore:

$I_{1}=\operatorname{tr}(B)=\lambda^{2}+2 I_{2}=\frac{1}{2}\left[I_{1}{ }^{2}-\operatorname{tr}\left(B^{2}\right)\right]=2 \lambda^{2}+1 \quad I_{3}=\lambda^{2}$.

The next consideration see e.g. Attard and Hunt (2004) for details, leads to some relationships between the constants $A_{i}$ :

$$
\begin{gathered}
A_{0}=4\left(A_{2}+16 A_{4}\right) \quad A_{1}=32 A_{4} \quad A_{3}=4 A_{4} \\
A_{5}=\frac{1}{3} A_{6} \quad A_{7}=-\frac{3}{4} A_{6} .
\end{gathered}
$$

Hence, the number of independent material parameters in this model for compressible hyperelasticity reduces to only three, namely $A_{2}, A_{4}$ and $A_{6}$. The constitutive relationship is now applied to onedimensional loading by combining of relationships given above; consequently, the stress, as a function of the stretch $\lambda$ is

$$
\sigma=\frac{\lambda^{2}-1}{\lambda^{2}}\left\{2 A_{2}+8 A_{4}\left(3 \lambda^{2}+5\right)+\frac{A_{6}}{2 \lambda^{2}}\right\} .
$$

The relationship between stretch $\lambda$ and engineering strain $\varepsilon$ is $\lambda=1+\varepsilon$. Data from the quasi-static tests are shown in the Fig. 4.

Values of the parameters $A_{2}, A_{4}$ and $A_{6}$ are presented in Table II.

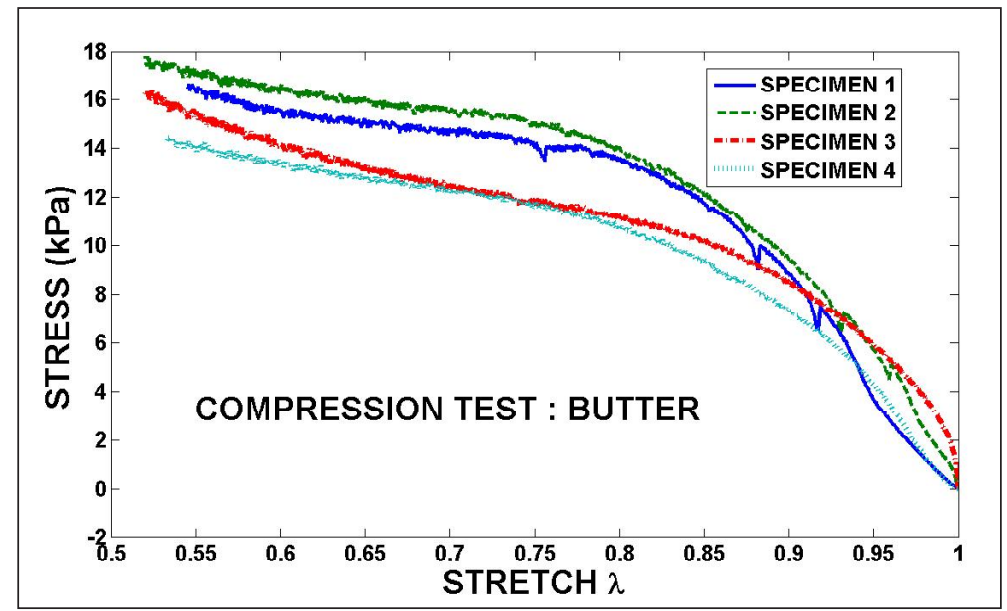

4: Stress vs. stretch

II: Parameters in proposed constitutive equation

\begin{tabular}{|c|c|c|c|c|}
\hline SPECIMEN & $\mathrm{A}_{2}(\mathrm{kPa})$ & $\mathrm{A}_{4}(\mathrm{kPa})$ & $\mathrm{A}_{6}(\mathrm{kPa})$ & $\mathrm{R}^{2}$ \\
\hline 1 & 0.1838 & -0.02841 & -0.007054 & 0.9922 \\
\hline 2 & 0.1831 & -0.02867 & -0.006388 & 0.9865 \\
\hline 3 & 0.1690 & -0.02592 & -0.006812 & 0.9170 \\
\hline 4 & 0.1406 & -0.02199 & -0.005100 & 0.9903 \\
\hline
\end{tabular}




\section{CONCLUSION}

The basic data on the strain behaviour of a butter under low strain rates have been obtained. The observed static response can be described by the hyperelasticity model based on an elastic strain energy potential with three parameters. It is found that a newly proposed polynomial series for this poten- tial energy function adequately describes the hyperelastic nature of the butter. The proposed model enables evaluation of the butter response to different types of loading. The next step in the development of the presented model should incorporate the effect of the strain rate. This research will be subject of the forthcoming papers.

\section{SOUHRN}

Konstitutivní rovnice másla při statickém zatěžování

Cílem této práce bylo stanovení konstitutivní rovnice másla vzhledem k tomu, že většina publikací se zabývá chováním másla při teplotách nad $25^{\circ} \mathrm{C}$ a při chladících teplotách mezi 5 a $10^{\circ} \mathrm{C}$, dat pro oblast teplot ležících mezi těmito hodnotami je minimum. V této práci stanovený model je použitelný pro máslo při teplotách $17-20{ }^{\circ} \mathrm{C}$. Použity byly vzorky komerčně dostupného másla s obsahem tuku 83 \%. Byla provedena experimentální a teoretická studia deformačního chování másla při statickém zatěžování. Z másla byly připraveny vzorky v podobě válečků s výškou 14,6 mm a průměrem $20 \mathrm{~mm}$. Vzorky byly stlačovány mezi dvěmi paralelními deskami konstantní rychlostí 20 mm/min za využití přístroje TIRATEST. V průběhu měření byla stanovena a zaznamenávána síla Fa deformace $\Delta L$. Hodnoty síla - deformace byly vyjádřeny jako napětí a deformace. Závislost skutečného napětí - skutečné deformace je charakterizována polynomem: $\sigma_{t}=a \varepsilon_{t}^{3}+b \varepsilon_{t}^{2}+c \varepsilon_{t}$. Parametry této křivky se pohybovaly v rozpětí 0,4003 až $0,5148 \mathrm{kPa}$ (parametr a), -0,3404 až -0,4034 kPa (parametr $b$ ) a v rozpětí 0,1016 až 0,1487 kPa (parametr $c$ ) s velmi vysokým korelačním koeficientem $\left(\mathrm{R}^{2}=0,9943-0,9992\right)$. Ukazuje se, že deformační chování másla, tzn. závislost napětí - deformace, je velmi podobné průběhu deformace polymerních pěn, jejichž chování je popsáno ověřenými modely. Na základě této podobnosti byla provedena analýza deformačního chování másla v rámci modelu tzv. hyperelastického materiálu. Ukazuje se, že tento model velmi dobře popisuje získané experimentální údaje. Daný model pak umožňuje popis chování másla př̀i pomalém, tzv. statickém zatěžování. Dalším krokem bude rozšíření modelu na oblast vyšších deformačních rychlostí.

máslo, tlakové zatěžování, napětí, deformace, konstitutivní rovnice

\section{SUMMARY}

The aim of this paper consists in the study of a proper constitutive model for butter because most of papers is focused on some flow properties of the butter which are typical for temperatures above about $25^{\circ} \mathrm{C}$ and for cooling temperature 5 to $10{ }^{\circ} \mathrm{C}$, the information about butter behaviour at temperatures lying between these two regions is very rare. The commercially obtained butter with $83 \%$ of milk fat has been used. This paper consists a proper constitutive model for butter at the temperatures between $17-20^{\circ} \mathrm{C}$. Experimental and theoretical study of behaviour of butter at static loading was made. Specimens - a cylindrical sample of height $L_{0}=14.6 \mathrm{~mm}$ and diameter $20 \mathrm{~mm}$ have been prepared from the same butter. The samples have been compressed between two parallel metal plates at a fixed crosshead speed $20 \mathrm{~mm} / \mathrm{min}$ using of the testing device TIRA TEST. The force $F$ and the deformation $\Delta L$ are measured during compression and both quantities are recorded. The force-deformation data may easily be transformed into normalized quantities such as stress and strain. The dependence true stress-true strain can be fitted by a polynom:. Parameters of the curve fitting range from 0.4003 to $0.5148 \mathrm{kPa}$ (parameter a), -0.3404 to $-0.4034 \mathrm{kPa}$ (parameter b) and from 0.1016 to $0.1487 \mathrm{kPa}$ (parameter c) with the correlation very high $\left(\mathrm{R}^{2}=0.9943-0.9992\right)$. The basic data on the strain behaviour of a butter under low strain rates have been obtained. The observed static response can be described by the hyperelasticity model based on an elastic strain energy potential with three parameters. As it has been remarked the obtained data are very similar to those obtained for elastomeric foams. It is found that a newly proposed polynomial series for this potential energy function adequately describes the hyperelastic nature of the butter. The proposed model enables evaluation of the butter response to different types of loading. The next step in the development of the presented model should incorporate the effect of the strain rate.

\section{REFERENCES}

ATTARD, M. M., HUNT, G. W., 2004: Hyperelastic constitutive modeling under finite strain. Interna- tional Journal of Solids and Structures, 41, 18-19, ISSN 0020-7683.

ENJALBERT, F., NICOT, M. C., BAYOURTHE, C., MONCOULON, R., 2000: Effects of Duodenal 
Infusions of Palmitic, Stearic, or Oleic Acids on Milk Composition and Physical Properties of Butter. Journal of Dairy Science, 83, 7: 1428-1433. ISSN 0022-0302.

LOCKETT, F. J., 1972: Nonlinear Viscoelastic Solids. New York: Academic Press Inc., 195 pp. ISBN 0124543502.

RIVLIN, R. S., 1960: Some topics in finite elasticity. In: Goodier, J. N. and Hoff, N. J. (eds.) Structural Mechanics: Proceedings of the First Symposium on $\mathrm{Na}$ val Structural Mechanics. New York, Pergamon Press, 169-198.
WANG, L. L., YANG, L. M., 1992: A class of nonlinear viscoelastic constitutive relation of solid polymeric materials. In: Wang, L. L., Yu, T. X. and Li, Y. C. (eds.) The progress in impact dynamics, University of Science and Technology of China, Hefei, 88-116.

ZHANG, J., LIN, Z., WONG, A., KIKUCHI, N., LI, V. C., YEE, A. F., NUSHOLTZ, G. S, 1997: Constitutive Modeling and Material Characterization of Polymeric Foams. Journal of Engineering Materials and Technology, 119, 3: 284-291. ISSN 0094-4289.

Ing. Šárka Nedomová, Ph.D., Ústav technologie potravin, Ing. Libor Severa, Ph.D., Ústav techniky a automobilové dopravy, Mendelova zemědělská a lesnická univerzita v Brně, Zemědělská 1, 61300 Brno, Česká republika, e-mail: snedomov@mendelu.cz. 